\title{
How people-centred health systems can reach the grassroots: experiences implementing community-level quality improvement in rural Tanzania and Uganda
}

\author{
Tara Tancred, ${ }^{1,2 *}$ Rogers Mandu, ${ }^{3}$ Claudia Hanson, ${ }^{2,4}$ Monica Okuga, ${ }^{3}$ Fatuma Manzi, ${ }^{1}$ \\ Stefan Peterson, ${ }^{3,4,5}$ Joanna Schellenberg, ${ }^{2}$ Peter Waiswa, ${ }^{3,4}$ Tanya Marchant ${ }^{2}$ and The EQUIP \\ Study Team \\ ${ }^{1}$ Ifakara Health Institute, Dar es Salaam, Tanzania ${ }^{2}$ Department of Disease Control, London School of Hygiene and Tropical Medicine, \\ London, UK ${ }^{3}$ Makerere University School of Public Health, Kampala, Uganda ${ }^{4}$ Department of Public Health Sciences, Karolinska Institutet, \\ Stockholm, Sweden and ${ }^{5}$ The Department of Women's and Children's Health, Uppsala University, Uppsala, Sweden \\ *Corresponding author. London School of Hygiene and Tropical Medicine, Keppel Street, London WC1E 7HT, UK. \\ E-mail: ttancred@gmail.com
}

\begin{abstract}
Accepted 25 June 2014
Background Quality improvement (QI) methods engage stakeholders in identifying problems, creating strategies called change ideas to address those problems, testing those change ideas and scaling them up where successful. These methods have rarely been used at the community level in low-income country settings. Here we share experiences from rural Tanzania and Uganda, where QI was applied as part of the Expanded Quality Management Using Information Power (EQUIP) intervention with the aim of improving maternal and newborn health. Village volunteers were taught how to generate change ideas to improve health-seeking behaviours and home-based maternal and newborn care practices. Interaction was encouraged between communities and health staff.
\end{abstract}

Aim To describe experiences implementing EQUIP's QI approach at the community level.

Methods A mixed methods process evaluation of community-level QI was conducted in Tanzania and a feasibility study in Uganda. We outlined how village volunteers were trained in and applied QI techniques and examined the interaction between village volunteers and health facilities, and in Tanzania, the interaction with the wider community also.

Results Village volunteers had the capacity to learn and apply QI techniques to address local maternal and neonatal health problems. Data collection and presentation was a persistent challenge for village volunteers, overcome through intensive continuous mentoring and coaching. Village volunteers complemented health facility staff, particularly to reinforce behaviour change on health facility delivery and birth preparedness. There was some evidence of changing social norms around maternal and newborn health, which EQUIP helped to reinforce.

Conclusions Community-level QI is a participatory research approach that engaged volunteers in Tanzania and Uganda, putting them in a central position within local health systems to increase health-seeking behaviours and improve preventative maternal and newborn health practices. 
Keywords Community participation, community mobilization, developing countries, health care seeking behaviour, health systems, maternal and child health, participatory research, qualitative research

\section{KEY MESSAGES}

- Quality improvement methods have been rarely used at the community level in low-income settings.

- Village volunteers can apply quality improvement to increase demand for maternal and newborn health services; link with health facilities; and influence positively changing social norms around maternal and newborn health.

- Continuous mentoring and coaching is needed to support village volunteers' work.

\section{Introduction}

Improvements in maternal and neonatal health have been prioritized internationally through the Millennium Development Goals 4 and 5 (United Nations Department of Economic and Social Affairs 2011). With over 98\% of maternal and neonatal deaths being concentrated in low- and middle-income countries, there is an obvious need to tailor efforts to these settings (WHO et al. 2012; United Nations 2013). Although gains have been made, the pace of improvement in maternal and neonatal mortality rates has been slow, with few interventions to-date being successful in markedly and sustainably reducing maternal and neonatal mortality at scale (Adam et al. 2005; Bhutta et al. 2005; 2010; Schiffman et al. 2010; Imdad and Bhutta 2013; Marston et al. 2013; Moyer et al. 2013; Prost et al. 2013). Uganda and Tanzania are two countries where maternal and newborn deaths have been slow to decline (WHO et al. 2010; UNICEF et al. 2012).

With the aim of improving both the supply of and the demand for quality maternal and newborn health services in Tanzania and Uganda (EQUIP 2011), the 'Expanded Quality Management Using Information Power to Improve Maternal and Newborn Health' (EQUIP) intervention has implemented quality improvement (QI) processes at the community, health facility, and district levels (Figure 1; EQUIP 2011).

\section{Quality improvement theory}

QI is a management philosophy that challenges vertical management approaches through the engagement of multiple stakeholders in the bottom-up identification of problems and the design of context-appropriate solutions (Bloor 1999). To address local problems in maternal and newborn health, EQUIP applied QI using an approach pioneered by the Institute for Healthcare Improvement (Langley 2009). The cornerstone of this approach is the plan-do-study-act or PDSA cycle, which is a structured approach for planning, implementing and testing a strategy to address a problem. The approach is designed to answer three key questions: What are we trying to accomplish? What changes can we make that will result in an improvement? How will we know that change is an improvement? (Langley 2009) The PDSA cycles are then used to plan and test strategies (called 'change ideas') to ensure that improvements are made.

\section{Community-level quality improvement}

Typically, QI has been used at the facility or administrative level, and rarely at the community level, especially within lowand middle-income country settings (Umar et al. 2009). Three examples of where community members have been engaged in QI are from the Democratic Republic of Congo, Vietnam and Ethiopia. In the first two, the primary aim was to improve health services (du Mortier and Arpagaus 2005; Wallin et al. 2011). In Ethiopia, QI was used to increase health-seeking behaviours (Sibley et al. 2014). Community-level QI within EQUIP also aims to increase health-seeking behaviours and to improve preventative maternal and newborn care practices. Overall, an innovative aspect of EQUIP is that community, health facility, and district-level QI occurred simultaneously, and community QI was done exclusively by community members for community members.

\section{EQUIP's community-level quality improvement in Tanzania and Uganda}

The use of QI within EQUIP, with its emphasis on change ideas that are continually generated, evaluated, and modified by community members, can be considered as a participatory research approach. Participatory research here is defined as research that focuses on locally defined priorities and local perspectives, involving community members as research participants (Cornwall and Jewkes 1995).

The EQUIP intervention is described in detail elsewhere (Hanson et al. 2014). In both Tanzania and Uganda, the intervention was implemented in one district (Tandahimba in Tanzania, Mayuge in Uganda) using a neighbouring district as a comparator for effect evaluation. The intervention pilot began in September of 2011 and reached district-level scale throughout all communities by August 2012 in Tanzania and January 2013 in Uganda.

Here, we describe the experience implementing EQUIP's QI approach at the community level for increased demand for maternal and newborn health services and improved community-level maternal and newborn care practices. 


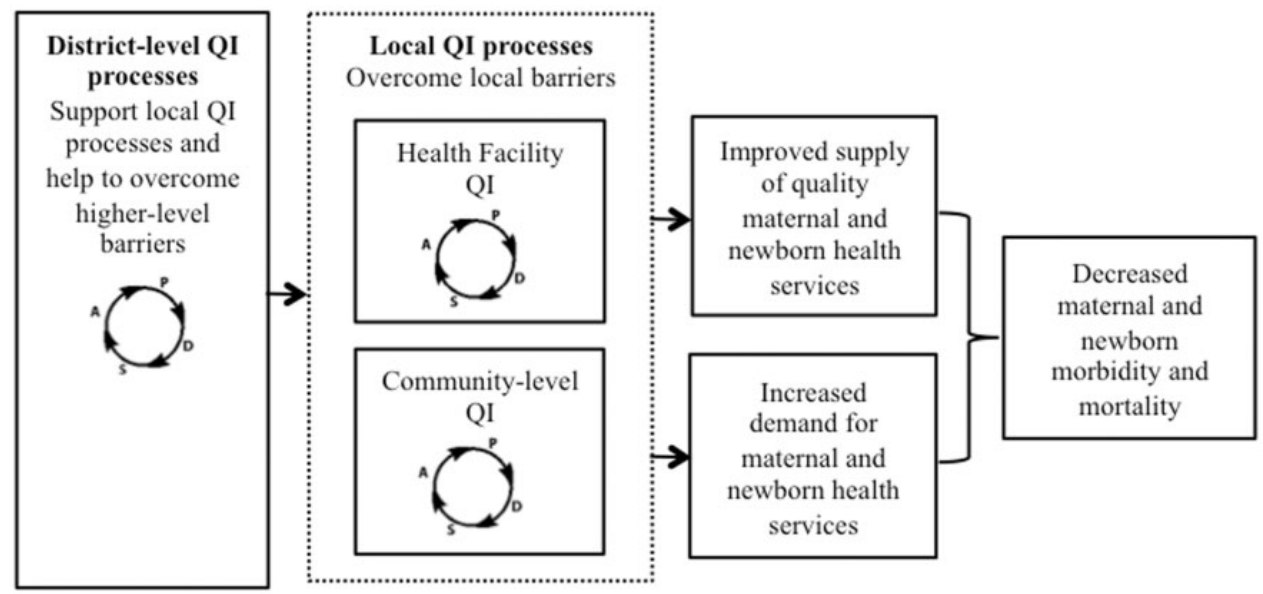

Figure 1 EQUIP's conceptual framework for quality improvement at the district, health facility, and community levels to reduce maternal and newborn morbidity and mortality.

\section{Methods}

Figure l highlights the conceptual framework of EQUIP, showing how the three levels of the intervention can interact with one another to increase both the supply of and demand for quality maternal and newborn health services. The methods described below explored the implementation of the EQUIP intervention, which was ongoing until April 2014. An overall evaluation of EQUIP's impact on maternal and newborn health indicators will follow.

\section{Tanzania}

Qualitative data were collected from November 2012-2013 as part of an in-depth mixed methods process evaluation of the community-level QI activities. The objective of this process evaluation was to uncover the main barriers and facilitators of community-level QI.

\section{Study setting}

The total population of the intervention district, Tandahimba, is 227514 (National Bureau of Statistics 2013), with the most prominent ethnic group being the Makonde (The Planning Commission United Republic of Tanzania 1997). Agriculture employs over $94 \%$ of the population in Tandahimba (Mkai and Mbogoro 2004). The maternal mortality ratio from 2004 to 2007 was 712 (95\% confidence interval 652-777) per 100000 live births in six districts of the southern zone including Tandahimba (Hanson 2013) and the neonatal mortality rate estimate was 31 deaths in the first 28 days of life per 1000 live births in 2010 (National Bureau of Statistics \& ICF Macro 2011), both of which are higher than Tanzania's national estimates.

Within EQUIP, each of the 157 villages in Tandahimba had two village volunteers for a total of 314 village volunteers. Volunteers were eligible for selection by village leaders and/or community members if they were literate, permanent residents of the village. Volunteers from 15-to-18 villages formed groups that met monthly; there were 10 volunteer groups in total, and a government education extension worker with a background in teaching acted as a QI mentor for each group. In addition to monthly meetings, every three months volunteers from threeto-four volunteer groups came together to participate in a meeting called a learning session. Three learning sessions were held every quarter throughout Tandahimba district. Here volunteers reviewed progress and received information about new topics related to maternal and newborn health. At learning sessions, volunteers had the opportunity to present their own data and exchange with one another. A community district mentor, also a government community development officer, facilitated these learning sessions together with volunteer group QI mentors (extension workers) and EQUIP staff. At learning sessions, change ideas were developed, each with work plans outlining exactly how those change ideas would be tested. The interval of three months between learning sessions was referred to as an 'action period' in which change ideas were implemented on a small scale and data were collected to evaluate them. These change ideas were then adapted and tested again or scaled up and monitored if successful. Volunteers used PDSA cycles to guide them through the creation, testing, and scaling up of change ideas. Table 1 shows the implementers of the EQUIP intervention and their activities.

\section{Data collection and management}

Four villages in Tandahimba district were purposively sampled for this study on the basis of their diversity. These villages differed regarding proximity to health facilities, level of referral health facility (dispensary, health centre or hospital), primary economic activities, predominant religion, and age and education levels of their volunteers. Volunteers in all four villages were active for at least six months before the onset of the process evaluation.

Table 2 indicates the qualitative data collection methods used. In addition, learning sessions and volunteer group monthly meetings were observed. All interviews, birth narratives, and focus group discussions were piloted, revised and implemented in Swahili by two trained interviewers. Audio data were then transcribed and translated into English. TT and both interviewers kept extensive field notes, which were debriefed daily. For data quality control, the translated transcripts were checked 
Table 1 Overview of EQUIP implementers in both Tanzania and Uganda, their responsibilities, time required for responsibilities and incentives or reimbursement provided

\begin{tabular}{|c|c|c|c|c|}
\hline $\begin{array}{l}\text { EQUIP } \\
\text { intervention } \\
\text { implementer }\end{array}$ & Total number & Activities & $\begin{array}{l}\text { Time required for } \\
\text { responsibilities }\end{array}$ & $\begin{array}{l}\text { Allowances and reimbursement } \\
\text { provided by EQUIP }\end{array}$ \\
\hline \multicolumn{5}{|l|}{ Tanzania } \\
\hline \multirow[t]{3}{*}{ Village volunteers } & \multirow[t]{3}{*}{$\begin{array}{l}314 \text { (two per village } \\
\text { in each of } 157 \\
\text { villages) }\end{array}$} & $\begin{array}{l}\text { Learning sessions: one volunteer per } \\
\text { village (alternating each learning } \\
\text { session) attends to problem solve } \\
\text { and develop change ideas with } \\
\text { support from extension workers, } \\
\text { community-level district mentor, } \\
\text { and EQUIP staff }\end{array}$ & $\begin{array}{l}\text { One day every three } \\
\text { months }\end{array}$ & $\begin{array}{l}\text { Sitting allowance ( } 25000 \\
\text { Tanzanian shillings, } \sim \$ 15.90 \\
\text { United States Dollars (USD)) per } \\
\text { volunteer per learning session } \\
\text { attended }\end{array}$ \\
\hline & & $\begin{array}{l}\text { Action period: test and implement } \\
\text { change ideas at community-level; } \\
\text { collect routine monitoring data }\end{array}$ & One day per week & No allowances provided by EQUIP \\
\hline & & $\begin{array}{l}\text { Mentoring and coaching: participa- } \\
\text { tion in monthly volunteer } \\
\text { meetings }\end{array}$ & $\begin{array}{l}\text { Two-to-four hours per } \\
\text { month }\end{array}$ & $\begin{array}{l}\text { Transportation allowance }(5000 \\
\text { Tanzanian shillings, } \sim \$ 3.20 \text { USD) } \\
\text { per volunteer per meeting } \\
\text { attended }\end{array}$ \\
\hline \multirow[t]{5}{*}{$\begin{array}{l}\text { Volunteer group } \\
\text { QI mentors } \\
\text { (extension } \\
\text { workers) }\end{array}$} & \multirow[t]{5}{*}{$\begin{array}{l}10 \text { (one to supervise } \\
\text { volunteers from } 15 \\
\text { to } 18 \text { villages) }\end{array}$} & $\begin{array}{l}\text { Learning sessions: provide support } \\
\text { to volunteers during learning } \\
\text { sessions }\end{array}$ & $\begin{array}{l}\text { Two days every three } \\
\text { months (one day prior } \\
\text { to learning session for } \\
\text { preparation) }\end{array}$ & $\begin{array}{l}\text { Sitting allowance ( } 25000 \\
\text { Tanzanian shillings, } \sim \$ 15.90 \\
\text { USD) per extension worker per } \\
\text { learning session attended }\end{array}$ \\
\hline & & $\begin{array}{l}\text { Mentoring and coaching: facilitate } \\
\text { monthly volunteer meeting }\end{array}$ & One day per month & $\begin{array}{l}\text { Sitting allowance ( } 10000 \\
\text { Tanzanian shillings, } \sim \$ 6.40 \text { USD) } \\
\text { per meeting per extension worker } \\
\text { per meeting attended }\end{array}$ \\
\hline & & \multirow{2}{*}{$\begin{array}{l}\text { Mentoring and coaching: verify } \\
\text { volunteer activities and data from } \\
\text { each village. Visit volunteers from } \\
\text { five-to-six villages each month. } \\
\text { Each volunteer is followed-up by } \\
\text { their extension worker in their } \\
\text { respective villages once per action } \\
\text { period }\end{array}$} & \multirow[t]{3}{*}{$\begin{array}{l}\text { Two-to-three days per } \\
\text { month }\end{array}$} & $\begin{array}{l}\text { Fuel allowance ( } 20000 \text { Tanzanian } \\
\text { shillings, } \sim \$ 12.75 \text { USD) per } \\
\text { extension worker per month }\end{array}$ \\
\hline & & & & $\begin{array}{l}\text { Communication allowance ( } 10000 \\
\text { Tanzanian shillings, } \sim \$ 6.40 \text { USD; } \\
\text { three extension workers with } \\
\text { larger groups receive } 15000 \\
\text { Tanzanian shillings, } \sim \$ 9.55 \text { USD) }\end{array}$ \\
\hline & & $\begin{array}{l}\text { Collecting data from volunteers to } \\
\text { community mentor/EQUIP staff }\end{array}$ & & for phone credit per month \\
\hline \multirow[t]{4}{*}{$\begin{array}{l}\text { Community-level } \\
\text { district mentor }\end{array}$} & \multirow[t]{4}{*}{ One } & $\begin{array}{l}\text { Learning sessions: plans and facili- } \\
\text { tates learning sessions and vol- } \\
\text { unteer QI mentor meetings with } \\
\text { EQUIP staff }\end{array}$ & $\begin{array}{l}\text { Four days every three } \\
\text { months (one day for } \\
\text { preparation and one } \\
\text { day for each of the } \\
\text { three learning sessions } \\
\text { that happen through- } \\
\text { out the district) }\end{array}$ & $\begin{array}{l}\text { Sitting allowance to attend and } \\
\text { facilitate learning sessions } \\
\text { ( } 35000 \text { Tanzanian shillings, } \\
\sim \$ 22.30 \text { USD) per learning ses- } \\
\text { sion attended }\end{array}$ \\
\hline & & $\begin{array}{l}\text { Mentoring and coaching: helps to } \\
\text { facilitate monthly volunteer } \\
\text { meetings } \\
\text { Mentoring and coaching: oversees } \\
\text { activities of extension workers } \\
\text { through mentoring and coaching }\end{array}$ & \multirow[t]{3}{*}{$\begin{array}{l}\text { Five days per month } \\
\text { with more added as } \\
\text { required }\end{array}$} & $\begin{array}{l}\text { Transportation provided by EQUIP } \\
\text { Daily allowance ( } 20000 \text { Tanzanian } \\
\text { shillings, } \$ 12.75 \text { USD) to attend } \\
\text { and help facilitate monthly vol- } \\
\text { unteer meetings and to conduct } \\
\text { follow-up with extension workers } \\
\text { per day worked per month }\end{array}$ \\
\hline & & $\begin{array}{l}\text { Mentoring and coaching: collects } \\
\text { data from each cluster from ex- } \\
\text { tension workers }\end{array}$ & & \multirow[t]{2}{*}{$\begin{array}{l}\text { Communication allowance ( } 10000 \\
\text { Tanzanian shillings, } \sim \$ 6.40 \text { USD } \\
\text { for phone credit per month }\end{array}$} \\
\hline & & $\begin{array}{l}\text { Mentoring and coaching: conducts } \\
\text { some village-level follow-up with } \\
\text { volunteers }\end{array}$ & & \\
\hline EQUIP staff & One & $\begin{array}{l}\text { Mentoring and coaching: teaches QI } \\
\text { to district and volunteer QI } \\
\text { mentors }\end{array}$ & $\begin{array}{l}\text { Employed full-time for } \\
\text { EQUIP activities } \\
(40+\text { hours per week) }\end{array}$ & Salary \\
\hline
\end{tabular}


Table 1 Continued

\begin{tabular}{|c|c|c|c|c|}
\hline $\begin{array}{l}\text { EQUIP } \\
\text { intervention } \\
\text { implementer }\end{array}$ & Total number & Activities & $\begin{array}{l}\text { Time required for } \\
\text { responsibilities }\end{array}$ & $\begin{array}{l}\text { Allowances and reimbursement } \\
\text { provided by EQUIP }\end{array}$ \\
\hline & & $\begin{array}{l}\text { Learning sessions: plans and facili- } \\
\text { tates learning sessions and vol- } \\
\text { unteer QI mentor meetings with } \\
\text { district mentor }\end{array}$ & & \\
\hline & & $\begin{array}{l}\text { Mentoring and coaching: conducts } \\
\text { some village-level follow-up with } \\
\text { volunteers }\end{array}$ & & \\
\hline & & $\begin{array}{l}\text { Other: administrative duties and } \\
\text { overall monitoring and evaluation }\end{array}$ & & \\
\hline \multicolumn{5}{|l|}{ Uganda } \\
\hline \multirow[t]{2}{*}{ Village volunteers } & $\begin{array}{l}976 \text { (two from each } \\
\text { of } 488 \text { villages) }\end{array}$ & $\begin{array}{l}\text { Action period: use PDSA cycles to } \\
\text { create and implement change } \\
\text { ideas; collect and present local } \\
\text { data }\end{array}$ & Two days per month & No allowances provided by EQUIP \\
\hline & & Attendance of meetings each month & Half a day per month & $\begin{array}{l}\text { Transportation allowance and re- } \\
\text { freshment provision ( } 11500 \\
\text { Ugandan shillings, } \sim \$ 4.80 \text { USD) } \\
\text { per volunteer per meeting } \\
\text { attended }\end{array}$ \\
\hline \multirow[t]{2}{*}{$\begin{array}{l}\text { Community vol- } \\
\text { unteer group } \\
\text { members }\end{array}$} & $\begin{array}{l}144 \text { (two from each } \\
\text { of } 72 \text { parishes) }\end{array}$ & $\begin{array}{l}\text { Learning sessions: each volunteer } \\
\text { attends to problem solve and } \\
\text { develop change ideas with sup- } \\
\text { port from mentors and EQUIP } \\
\text { staff }\end{array}$ & $\begin{array}{l}\text { One day per three } \\
\text { months }\end{array}$ & $\begin{array}{l}\text { Transportation allowance and re- } \\
\text { freshment provision ( } 15000 \\
\text { Ugandan shillings, } \sim \$ 6.30 \text { USD) } \\
\text { per volunteer per learning session } \\
\text { attended }\end{array}$ \\
\hline & & $\begin{array}{l}\text { Action period: pass on education to } \\
\text { other volunteers in each parish } \\
\text { Action period: use PDSA cycles to } \\
\text { create and implement change } \\
\text { ideas; collect and present local } \\
\text { data }\end{array}$ & $\begin{array}{l}\text { Approximately two-to- } \\
\text { three days per month }\end{array}$ & $\begin{array}{l}\text { Motivation allowance ( } 5500 \\
\text { Ugandan shillings, } \sim \$ 2.30 \text { USD) } \\
\text { per volunteer per month }\end{array}$ \\
\hline \multirow[t]{3}{*}{$\begin{array}{l}\text { Sub-district } \\
\text { mentors }\end{array}$} & 30 & $\begin{array}{l}\text { Learning sessions: provide support } \\
\text { to volunteers }\end{array}$ & $\begin{array}{l}\text { One-and-a-half days } \\
\text { every three months } \\
\text { (half a day prior to the } \\
\text { learning session for } \\
\text { preparation, one day } \\
\text { for the learning ses- } \\
\text { sion itself) }\end{array}$ & \multirow[t]{3}{*}{$\begin{array}{l}\text { Fuel reimbursement (20 } 000 \\
\text { Ugandan shillings, } \sim \$ 8.35 \text { USD) } \\
\text { per mentor per month } \\
\text { Daily working allowance ( } 12000 \\
\text { Ugandan shillings, } \sim \$ 5.00 \mathrm{USD} \text { ) } \\
\text { per mentor per day worked each } \\
\text { month }\end{array}$} \\
\hline & & $\begin{array}{l}\text { Mentoring and coaching: facilitate } \\
\text { monthly volunteer meetings }\end{array}$ & $\begin{array}{l}\text { Typically three-to-four } \\
\text { days per month }\end{array}$ & \\
\hline & & $\begin{array}{l}\text { Mentoring and coaching: collect } \\
\text { data from each parish }\end{array}$ & & \\
\hline \multirow[t]{3}{*}{$\begin{array}{l}\text { District commu- } \\
\text { nity mentors }\end{array}$} & Two & $\begin{array}{l}\text { Learning sessions: plan and facili- } \\
\text { tate learning sessions and sub- } \\
\text { district mentor meetings with } \\
\text { EQUIP staff }\end{array}$ & $\begin{array}{l}\text { Six-and-a-half days } \\
\text { every three months } \\
\text { (half a day for prep- } \\
\text { aration, six days for } \\
\text { the learning sessions) } \\
\text { per mentor }\end{array}$ & \multirow{3}{*}{$\begin{array}{l}\text { Fuel reimbursement ( } 45000 \\
\text { Ugandan shillings, } \sim \$ 18.80 \text { USD) } \\
\text { per mentor per month } \\
\text { Daily working allowance ( } 12000 \\
\text { per day worked } \sim \$ 5.00 \text { USD) } \\
\text { per mentor per day worked each } \\
\text { month }\end{array}$} \\
\hline & & $\begin{array}{l}\text { Mentoring and coaching: oversee } \\
\text { activities of sub-district mentors }\end{array}$ & $\begin{array}{l}\text { Typically, } 15 \text { days per } \\
\text { mentor per month }\end{array}$ & \\
\hline & & $\begin{array}{l}\text { Mentoring and coaching: collect } \\
\text { data from each sub-district } \\
\text { mentor }\end{array}$ & & \\
\hline \multirow[t]{4}{*}{ EQUIP staff } & One & $\begin{array}{l}\text { Mentoring and coaching: teaches QI } \\
\text { to district and sub-district QI } \\
\text { mentors }\end{array}$ & $\begin{array}{l}\text { Employed full-time for } \\
\text { EQUIP activities } \\
(40+\text { hours per week })\end{array}$ & $\begin{array}{l}\text { Salary } \\
\text { Transport to the field provided by } \\
\text { EQUIP }\end{array}$ \\
\hline & & $\begin{array}{l}\text { Learning sessions: plan and facili- } \\
\text { tate learning sessions with } \\
\text { mentors }\end{array}$ & & \\
\hline & & $\begin{array}{l}\text { Mentoring and coaching: attends } \\
\text { mentor and some volunteer QI } \\
\text { meetings }\end{array}$ & & \\
\hline & & $\begin{array}{l}\text { Other: administrative duties and } \\
\text { overall monitoring and evaluation }\end{array}$ & & \\
\hline
\end{tabular}


Table 2 Process evaluation data collection methods and participants

\begin{tabular}{|c|c|c|c|c|c|c|}
\hline Method & Participants & Timing & $\begin{array}{l}\text { Total } \\
\text { number }\end{array}$ & Male & Female & Participant characteristics \\
\hline \multirow{12}{*}{$\begin{array}{l}\text { In-depth } \\
\text { interviews }\end{array}$} & \multirow[t]{2}{*}{ Village volunteers } & November 2012 & 8 & 4 & 4 & \multirow[b]{2}{*}{$\begin{array}{l}\text { Two from each of the four sampled villages; age } \\
\text { range } 21 \text {-to- } 52 \text { years; most married, three of the } \\
\text { younger volunteers unmarried; all literate; half } \\
\text { have completed eleven or more years of } \\
\text { education (form four leavers), half have only } \\
\text { primary school education. Same participants } \\
\text { interviewed twice. }\end{array}$} \\
\hline & & October 2013 & 8 & 4 & 4 & \\
\hline & \multirow{2}{*}{$\begin{array}{l}\text { Volunteer group QI } \\
\text { mentors (exten- } \\
\text { sion workers) }\end{array}$} & November 2012 & 2 & 1 & 1 & \multirow{2}{*}{$\begin{array}{l}\text { Each responsible for two of the four villages, } \\
52 \text {-years-old and } 34 \text {-years-old. Same partici- } \\
\text { pants interviewed twice. }\end{array}$} \\
\hline & & October 2013 & 2 & 1 & 1 & \\
\hline & Village leaders & May 2013 & 4 & 4 & 0 & One from each of the four sampled villages \\
\hline & \multirow[t]{2}{*}{ Health facility staff } & May 2013 & 4 & 2 & 2 & \multirow{2}{*}{$\begin{array}{l}\text { Each from the main referral health facility for } \\
\text { each of the four sampled villages: two dispen- } \\
\text { saries, one health centre, and one district } \\
\text { hospital; age range } 26 \text {-to- } 58 \text { years. Same par- } \\
\text { ticipants interviewed twice. }\end{array}$} \\
\hline & & October 2013 & 4 & 2 & 2 & \\
\hline & \multirow{2}{*}{$\begin{array}{l}\text { District community } \\
\text { QI mentor }\end{array}$} & November 2012 & 1 & 1 & 0 & \multirow{2}{*}{$\begin{array}{l}\text { Overall supervisor of community-level QI. Same } \\
\text { participant interviewed twice. }\end{array}$} \\
\hline & & November 2013 & 1 & 1 & 0 & \\
\hline & \multirow[t]{2}{*}{ EQUIP staff } & December 2012 & 2 & 1 & 1 & \multirow{2}{*}{$\begin{array}{l}\text { All EQUIP staff responsible for supporting com- } \\
\text { munity-level QI at various points in the } \\
\text { intervention. }\end{array}$} \\
\hline & & November 2013 & 1 & 1 & 0 & \\
\hline & Mothers & May 2013 & 12 & 0 & 12 & $\begin{array}{l}\text { Age range 16-to- } 39 \text { years; first child to fourth } \\
\text { child; four home births, eight facility births. }\end{array}$ \\
\hline \multirow[t]{2}{*}{$\begin{array}{l}\text { Focus group } \\
\text { discussions }\end{array}$} & \multirow[t]{2}{*}{ Village volunteers } & May 2013 & $\begin{array}{l}3 \text { focus } \\
\text { groups }\end{array}$ & 11 & 19 & \multirow{2}{*}{$\begin{array}{l}\text { Representatives from } 28 \text { villages with one of the } \\
\text { same extension workers as the four villages } \\
\text { sampled for the process evaluation, but } \\
\text { excluding volunteers from the four sampled } \\
\text { villages. Six volunteers who participated in May } \\
\text { focus groups also participated in November. }\end{array}$} \\
\hline & & November 2013 & $\begin{array}{l}2 \text { focus } \\
\text { groups }\end{array}$ & 5 & 9 & \\
\hline \multirow[t]{2}{*}{$\begin{array}{l}\text { Birth } \\
\text { narratives }\end{array}$} & \multirow[t]{2}{*}{ Mothers and fathers } & July 2013 & 19 & 7 & 12 & $\begin{array}{l}\text { Mothers: age range } 17 \text {-to- } 44 \text { years; first child to } \\
\text { fifth child; eight facility births, four home } \\
\text { births; one mother to twins. } \\
\text { Fathers: age range } 21 \text {-to- } 60 \text { years; first child to } \\
\text { eighth child; partners had four facility births, } \\
\text { three home births. }\end{array}$ \\
\hline & & October 2013 & 17 & 6 & 11 & $\begin{array}{l}\text { Mothers: age range } 18 \text {-to- } 41 \text { years; first child to } \\
\text { sixth child; seven facility births, four home } \\
\text { births; one Caesarean section. } \\
\text { Fathers: age range } 24 \text {-to-55 years; first child to } \\
\text { eighth child; partners had three facility births, } \\
\text { two home births, and one delivered on the way } \\
\text { to the facility }\end{array}$ \\
\hline \multirow[t]{2}{*}{$\begin{array}{l}\text { Key informant } \\
\text { interviews }\end{array}$} & $\begin{array}{l}\text { Non-governmental } \\
\text { organization } \\
\text { representatives }\end{array}$ & July 2013 & 3 interviews & 3 & 1 & $\begin{array}{l}\text { Four representatives from the three organizations } \\
\text { identified by village leaders to be active in the } \\
\text { four villages sampled as part of the process } \\
\text { evaluation }\end{array}$ \\
\hline & $\begin{array}{l}\text { Government } \\
\text { representative }\end{array}$ & July 2013 & 1 & 1 & 0 & $\begin{array}{l}\text { One representative of the government social } \\
\text { development initiative indicated by village } \\
\text { leaders to be active in at least one of the four } \\
\text { villages sampled for the process evaluation }\end{array}$ \\
\hline
\end{tabular}

against the original audio and verified by a fluent EnglishSwahili speaker.

\section{Uganda}

In Uganda, results are from a feasibility study conducted in March of 2013 in Mayuge district with the aim of assessing the acceptability and feasibility of the EQUIP intervention.

\section{Study setting}

Mayuge district borders Lake Victoria and has a population of 412 500 (Uganda Bureau of Statistics, 2009). The major economic activities here are fishing and agriculture (Mayuge District Government, 2010). The maternal mortality ratio in the East Central region where Mayuge is located was 438 per 100000 live births and the neonatal mortality rate was 23 per 1000 live births in 2011 (Uganda Bureau of Statistics \& ICF International, 2012). 
The implementation of EQUIP and use of PDSA cycles in Uganda mirrored that of Tanzania, but with organizational differences. There were two EQUIP village volunteers from each of 488 villages in Mayuge, excluding 22 island villages, for 976 volunteers in total. Mayuge is subdivided into 72 parishes (each representing seven or eight villages). Two volunteer representatives were selected from each parish to make communitylevel volunteer groups that came together for learning sessions every three months, as in Tanzania. Two overall district community QI mentors and 30 sub-district-level mentors, who were employed by the government to oversee community mobilization activities, supported these 72 QI teams and village volunteers (Table 1). In both countries, EQUIP tapped into preexisting government employees present at the community level.

\section{Data collection and management}

In-depth interviews were conducted in the Lusoga language by a trained interviewer with four village volunteers, five health facility staff, one government community development officer, and two district QI community and health facility mentors. Participants were purposively selected from a pool of individuals who had been active with EQUIP for a year or longer. Data collection tools were piloted and revised prior to data collection.

\section{Data analysis}

In both Tanzania and Uganda, translated scripts were read and re-read multiple times. An overall coding frame was developed, with codes added as the scripts were reviewed line-by-line. Data were coded and analysed with NVivo 9 software. Data were analysed between each data collection period, and interview and focus group guides were modified in order to follow-up on findings until all major emerging themes had been explored. A thematic analysis approach was conducted to draw relationships between codes and to generate themes from the data (Pope et al. 2000). Although the number of points of data collection was pre-meditated, it was clear from the consistencies in participant responses that theoretical saturation had been reached. Representative quotations from themes were selected to display results.

\section{Ethical considerations}

Written informed consent was sought from all participants. Where participants were not literate, a verbal explanation of the informed consent sheet was given with a literate witness present-the participant provided a thumbprint.

\section{Results}

The results are presented in three sections. The first describes how village volunteers were trained in QI and how they began to use new knowledge and research skills. The second demonstrates how volunteers were able to work complementarily with health facility staff through EQUIP. The third, with examples from Tanzania only, highlights perceived changing social norms around maternal and newborn health.

\section{Village volunteers were trained successfully in quality improvement-a participatory research approach}

Volunteers were trained in QI and the application of PDSAs at the first learning session. Subsequent learning sessions and monthly meetings were an opportunity to provide volunteers with more detailed knowledge and to teach them additional QI methodologies. Between November 2011 and July 2013, a total of four topics (focus areas of maternal and newborn health that village volunteers were educated about during learning sessions) were introduced in Tanzania and nine in Uganda (Table 3). EQUIP volunteers were taught to brainstorm around topics to identify problems in their communities and then to think of improvement objectives that were SMART: specific, measurable, achievable, realistic and time-bound (Doran 1981). Volunteers were then encouraged to design testable change ideas to meet these objectives. For many volunteers, this was the first time that they had thought in such a scientific way, and they perceived this to have helped them develop a new skill set.

"I mean, the knowledge I got from the project, if I compare with previous days, I am now well skilled." (In-depth interview, Tanzanian village volunteer, male)

Under the close guidance of QI mentors and EQUIP staff, volunteers were mentored to develop change ideas (Table 3) that were likely to be achievable. As a participatory research approach, volunteers indicated that they were responsible for creating change ideas through QI methods, and they appreciated those change ideas being tailored to their local context.

"I have the authority [to develop change ideas] because we are in this community, so we understand which methods work so that we can capture the community... it is not possible for a person to come from somewhere else and establish methods here at [village name]; I don't think she can." (In-depth interview, Tanzanian village volunteer, female)

Volunteers tested their change ideas by first applying them with a few people and data were then collected to determine if the change idea worked. If so, it was applied across their community and then continually monitored. In particular, the emphasis on defining measureable objectives with appropriate numerators and denominators allowed volunteers to appreciate how data could be collected to test and monitor change ideas. Furthermore, if volunteers recognized through testing that change ideas were not successful, they quickly moved to adapt their change ideas or to start again with a new one.

"After making the education reach the targeted group [pregnant women in my village], I will collect statistics that will enable me to understand how the situation is after the [test] is over. I will compare the initial data with the current data that I have to see how they are." (In-depth interview, Tanzanian village volunteer, male)

"Yes, we change [our change ideas after testing]. For example, we planned that we can educate [women] during the clinic health day [where babies are weighed], but...[we found] when you provide education [there], it is not sufficient, since the ones who bring the 
Table 3 Change ideas generated by village volunteers to address selected topics in maternal and newborn health

\begin{tabular}{clc}
\hline Country & Topic & Objective \\
\hline Tanzania & Facility delivery & $\begin{array}{c}\text { To increase the number of women } \\
\text { going to health facilities for } \\
\text { childbirth }\end{array}$
\end{tabular}
childbirth

Birth preparedness

Danger signs

Infection prevention and control

Uganda Antenatal care attendance

Birth preparedness

Health facility delivery

Post-natal care

Immunizations

Care for low-birthweight babies

Delayed bathing of infant after delivery

Exclusive breastfeeding

Recognition and referral for newborn danger signs

and newborn danger signs known women and their families prevention and control strategies known and used by women and their families

increase the number of wome and infants receiving post-natal immunized against polio and tuberculosis at birth

To increase the percentage of low birthweight newborns identified and followed up with kangaroo mother care

To increase the percentage of newery was delayed by at least 24 hours

To increase the percentage of newborns being exclusively breastfed referred to and receiving care at a health facility for danger signs
Volunteer-defined change ideas to achieve objectives

- House-to-house visits with women and their husbands (sometimes also other family members) to provide education about the importance of facility delivery

- Work with local leaders to enforce fines that penalize women who give birth at home

- Work with local leaders to enforce fines that penalize traditional birth attendants who assist women to give birth at home

- Work with traditional birth attendants to have them act as escorts for women in labour, bringing them to health facilities

- Community sensitization about facility delivery when babies are brought for growth monitoring

- Work with local leaders to provide education at village-level meetings

- House-to-house visits with women and their husbands (sometimes also other family members) to provide education about birth preparedness

- Ask women to confirm that birth items have been prepared

- Community sensitization about birth preparedness when babies are brought for growth monitoring

- Work with local leaders to provide education at village-level meetings

- House-to-house visits with women and their husbands (sometimes also other family members) to provide education about danger signs and responded to appropriately by

To increase the number of infection

To increase the percentage of women attending four antenatal care visits

- House-to-house visits with women and their husbands (sometimes also other family members) to provide education about infection prevention and control strategies

- Register all pregnant women and referring them for antenatal care services

- Conduct community sensitization meetings on the importance of antenatal care

- Escort women to health facilities to attend antenatal care

- Conduct home visits and educate women and their husbands

- Develop a birth preparedness checklist for all registered pregnant women in the community

- Form women's savings groups to ensure that money is available for birth preparedness and transport

- Register pregnant women in the community and refer them to delivery at the health facility using their expected delivery date

- Remind women close to their expected delivery date to go to the health facility for delivery

- Use expected delivery dates to visit mothers and newborns after delivery for post-natal care care within one week of delivery

To increase the percentage of infants borns whose first bath after deliv-

- Immediate referral of all newborns for immunization

- Conduct community demonstrations of kangaroo mother care using low birthweight babies

- Community sensitization through meetings on delayed bathing

- Community sensitization through meetings on exclusive breastfeeding

- Use role models ('expert clients') in the community using exclusive breastfeeding to give testimonies

To increase the percentage of newborns - Escort patients to the health facility

Notes: As many volunteers already have the responsibility of conducting growth monitoring, they use this opportunity as a platform to provide education. The women and/or girls bringing infants receive education here post-partum, which may contribute to community sensitization and overall trends in social norms. However, many volunteers also couple this education with household visits to pregnant women and their families, who are the target of this intervention. 
babies for weighing are young kids, so we saw that we should change that change idea, because if you educate those who bring them and they are young, how will she understand anything?" (In-depth interview, Tanzanian village volunteer, male)

Fines against both mothers who delivered at home and against traditional birth attendants who may have helped them to do so were used widely across the intervention district in Tanzania by village volunteers after they perceived the success of other volunteers using this approach. In some villages, however, volunteer change ideas focused on creating a new role for traditional birth attendants in which they were called upon to confirm a woman's labour and help to escort her to a health facility.

"The traditional birth attendants also understood us, and in the community there is no one who dares [to deliver at home]. If the labour pain starts, they go to the dispensary or hospital...the one who has been told to go and give birth at the big hospital goes there directly and nobody dares to deliver a mother at home." (In-depth interview, Tanzanian village volunteer, female)

It should also be noted that in practice, there were opportunities for negotiation around fines.

"I didn't provide [the fine]... because [the health facility staff] are careless. They are the ones who were not around on that day...when [my husband] went [to speak with the village executive officer], he explained the situation and it was found that [the health facility staff] was the one at fault." (Birth narrative, Tanzanian mother)

Data around the objectives targeted by change ideas were summarized monthly and presented as run charts (Figure 2), which were typically shared between volunteers at monthly meetings and also at learning sessions. Being responsible for collecting and presenting data was recognized by volunteers as a role that they valued and also one that increased their sense of importance within the intervention.

"Our reports are very important. When we submit reports they are very important here at [village name]." (In-depth interview, Tanzanian village volunteer, male)

However, consistent, correct data collection and documentation was a struggle in both countries due to the unfamiliarity of volunteers with such tasks. When run charts were initially introduced to volunteers, the majority were unable to grasp how to calculate percentages and plot them correctly. Additionally, in both countries, understanding the meaning of QI methodologies, e.g. applying PDSA cycles, was an ongoing challenge. Follow-up with volunteers was therefore done not only as part of mentoring and coaching on QI methods, but also to verify that activities linked to change ideas were being carried out as planned, and to ensure volunteer-collected data and plotting of run charts was correct.

"[Data] shows the progress of our work, where we are improving or declining. It urges us [volunteers] to work hard and achieve our

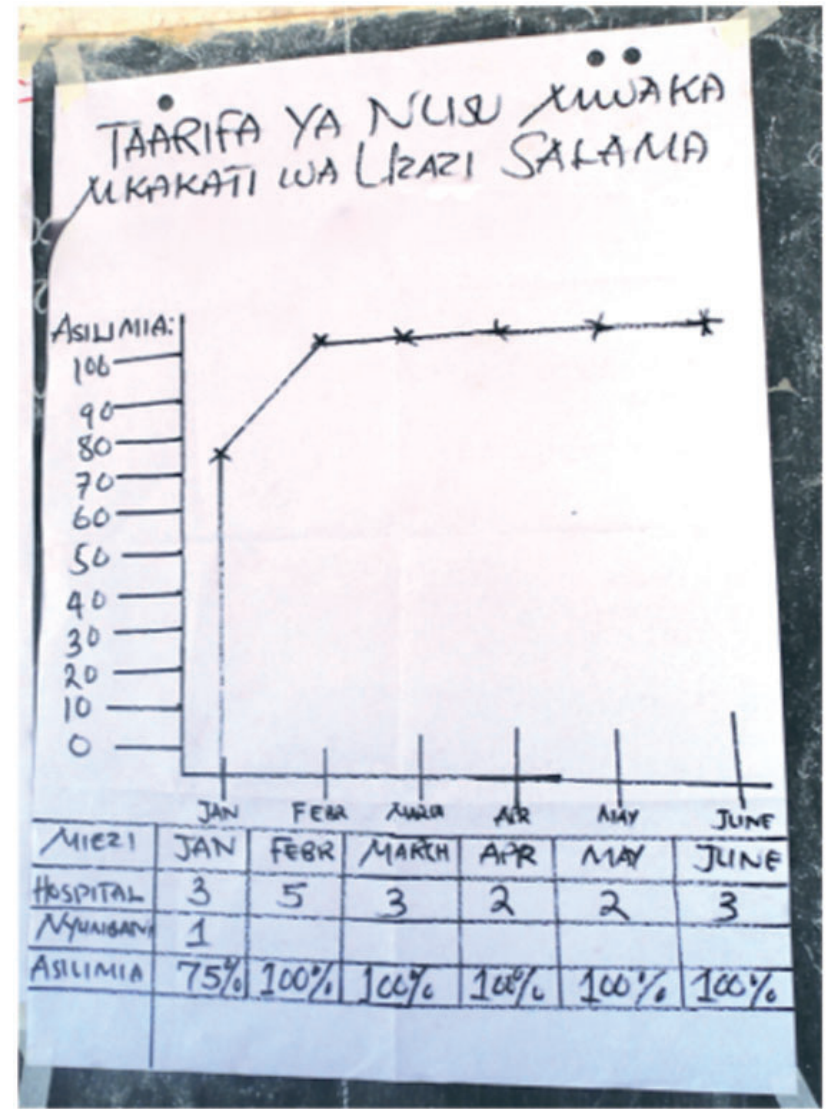

Figure 2 Photograph of an example run-chart (Taarifa ya nusu mwaka ya mkakati wa uzazi salama: half-year report of the safe delivery strategy) from a village in Tanzania showing the number of hospital (hospitali) and home (nyumbani) births with calculations of the percentage (asilimia) of facility deliveries over a six-month period.

objective. I like [collecting data] because it guides me to do what I am supposed to do. However, it is not easy to calculate the percentages and plot the graphs, even if we can read and write." (In-depth interview, Ugandan community-level QI volunteer)

"At first it was very difficult to understand and use the cycles because we are slow learners, but due to monthly mentoring sessions, we continued using the cycles and finally grasped it." (Indepth interview, Ugandan community-level QI volunteer)

Although volunteers experienced challenges in terms of mastering the QI work, and sometimes in gaining acceptance at the household level in their communities, overall, they appeared to be satisfied with their participation in the intervention. The most commonly cited benefits to them personally centred on the appreciation of new skills and knowledge. Helping to improve maternal and newborn health and contributing to development in their communities were also key benefits that volunteers recognized in doing this work.

"[EQUIP] has its importance because all in all, human beings are supposed to have good health. If one has [good health] then they will be able to work and we will develop as a nation... When I had started [in EQUIP] I didn't know about problems associated with 
babies and mothers, but as time went by, I understand, and [EQUIP] is important for [them]." (In-depth interview, Tanzanian village volunteer, male)

\section{Community members and health facility staff worked complementarily to provide education to community members to improve health-seeking behaviours}

Health facility staff were aware of and appreciated village volunteers and have noted the importance of their involvement.

"They have helped because now all pregnant women attend the health facility. They also tell traditional midwives not to help pregnant women to deliver at home, but to take them to the hospital for delivery." (In-depth interview, Tanzanian health facility staff, female)

Ninety-six per cent of women in Tanzania and Uganda access antenatal care in a health facility at least once during pregnancy (National Bureau of Statistics \& ICF Macro 2011, Larsson et al. 2012). Antenatal health education messages promoting health facility delivery and birth preparedness were the same as those promoted by EQUIP community volunteers. For example, community volunteers reiterated the education through a home visit and checked that all birth items had been prepared prior to the woman's expected delivery date. The shortage of health workers in many facilities also meant that, especially in lower-level facilities, volunteers directly took on a supportive role, assisting with educational messaging.

"When the [delivery] date nears, I ask her if all the [delivery items] are there, and if possible, she brings them outside to show me. In your book you put a tick to say that the mother has already prepared herself to go and give birth at the health facility." (Indepth interview, Tanzanian village volunteer, female)

"I am here at the health centre as a volunteer to educate women. I come here on antenatal care days, sometimes on immunization days to help educate women because people are many on those days. I help to educate them especially since health workers arrive late and don't have time to educate the women." (In-depth interview, Ugandan community-level QI volunteer)

Additionally, in Tanzania, health facility and communitylevel QI teams were encouraged to collaborate through monthly joint meetings in which they were able to discuss what each was working on and provided support where possible. There were instances of health facilities upholding village volunteer change ideas, e.g. by refusing to give a health card for babies delivered at home until women paid their fine to village leaders.

"Most of the time, we tell them you cannot get the card for your child until you go and see the village executive officer and explain to him as to why you delivered from home." (In-depth interview, Tanzanian health facility staff, male)

Despite the positive perception of health facility staff that health facility deliveries were increasing due in part to the work of the community-level EQUIP volunteers, they also noted the challenge of meeting increased demand. Community-level QI volunteers in both countries and mothers and fathers in Tanzania reiterated this concern and suggested that if women could not rely on health workers being present at facilities when they are ready to deliver, they were motivated to deliver at home with a traditional birth attendant.

\begin{abstract}
"The great work done by the [village volunteers] resulted in huge numbers of women attending antenatal care and also delivering at facilities, which is great. However, it also has a down side that we had a few staff who were overwhelmed." (In-depth interview, Ugandan district-level QI volunteer)

"I gave birth at home because, first, it was not a working day, second, there was not any worker at the health facility." (Birth narrative, Tanzanian mother)
\end{abstract}

These experiences highlight the importance of engaging both demand and supply sides of maternal and newborn health services, and present a barrier that could potentially be overcome through the district-level QI teams who are responsible for resource allocation.

\section{Emphasis placed on maternal and newborn health has helped to change social norms around maternal and newborn health at the village level in Tanzania}

A key factor that enabled EQUIP in volunteers' respective communities was the receptiveness and support of local leadership. Local leaders assisted volunteers by introducing them at community meetings, providing them with a community-wide platform to share their messages, follow-up their QI work and in some instances, attending learning sessions and monthly meetings to help volunteers develop change ideas and work plans. By engaging local leaders, the receptiveness and acceptance of the EQUIP intervention by community members increased, which primed the community for many of the changes advocated for by EQUIP.

"Yes, the villagers know the presence of this intervention because first we had introduced the volunteers in the various meetings. [We have been] sensitizing [households] that they should participate in all the activities that are being performed in the village." (In-depth interview, Tanzanian village executive officer, male)

Interviews with community members suggested that attitudes towards home births, traditional healers and traditional birth attendants were becoming increasingly less favourable, with women and their husbands seeing them as potentially dangerous, relying on them only as a last resort. This change in thinking was reported to be partly attributable to the change ideas created by village volunteers. These change ideas educated pregnant women and their families and prompted local leaders to actively move to sensitize traditional birth attendants and to dissuade pregnant women from accessing them.

"The traditional birth attendants are no longer working...it becomes difficult for a woman to give birth at home because they 
will not get assistance." (In-depth interview, Tanzanian village volunteer, male)

"Before, there were a lot of newborn and maternal deaths because of poor service from traditional birth attendants. Now many women are knowledgeable, also, many go to the health facility for delivery." (In-depth interview, Tanzanian mother)

Another emerging community-wide change during the study period was the inclusion of men in maternal and newborn health. In many of their change ideas, EQUIP village volunteers made a point of including partners and other family members when giving women education to ensure that they would enforce what was taught. In many instances, men were responsible for household financial resources and were therefore entrusted to purchase delivery items and to arrange money for transport when their partners went into labour. Men accepted this role and became more sensitized to their inclusion in maternal and newborn healthcare.

\begin{abstract}
"Men now co-operate in implementing [change ideas]; they co-operate with their families in buying items for delivery. In the past, it was a secret. When a woman was pregnant, men were not supposed to be involved in preparations, but now we are really together with men." (In-depth interview, Tanzanian village volunteer group QI mentor, male)
\end{abstract}

\section{Discussion}

Community-level QI is a participatory research approach that has engaged volunteers in Tanzania and Uganda, putting them in a central position within local health systems to improve community-level maternal and newborn health practices and increase the demand for health services. Results from our process evaluation in Tanzania and feasibility study in Uganda have identified multiple effects of community-level QI. Village volunteers have engaged with demand and supply side issues in maternal and newborn health, linkages between health facilities and communities have been strengthened, and complementary messaging from both health facilities and communities to improve birth preparedness and care-seeking for facility delivery were enabled.

The World Health Organization suggests that health systems encompass anything that promotes, maintains or restores health (World Health Organization 2007). By putting people at their centre, health systems can be made more responsive and accessible (Hunt and Backman 2008). EQUIP's communitylevel QI, therefore, is a valuable addition to local health systems. Furthermore, health systems benefit from synergy between both supply- and demand-side factors. For example, studies have found that an increase in skilled attendance at delivery may not affect maternal mortality if attendants are not adequately trained and if resources and a functioning referral system are not also present (Prata et al. 2009; Shah and Say 2007). EQUIP stands as an example of an intervention that facilitates community and health facility co-operation for health systems strengthening through co-ordinated demand and supply side actions.
Alongside other community-based interventions and initiatives, EQUIP's village volunteers were observed to play a part in changing social norms around traditional practices related to maternal and newborn health. The importance of engaging community members when trying to target health-seeking behaviours has been acknowledged across multiple settings (Bhutta et al. 2011; Rutenberg and Watkins 1997; Shaikh and Hatcher 2005). Social norms are reflected in an individual's health decisions, as they are likely to behave according to how the community will view his or her actions (Rutenberg and Watkins 1997). Therefore, QI that engages community members to improve health-seeking behaviours may also succeed in helping to positively change social norms in ways supply side interventions alone cannot. EQUIP is one of several community-level interventions to focus on maternal and newborn health. Therefore, women and their families received similar information from multiple sources, which, although perhaps a nuisance, allowed for the reinforcement of messaging. Thus, the momentum of changing norms around maternal and newborn health could be built and sustained collaboratively.

The use of PDSA cycles within EQUIP is similar to participatory action cycles, examples of which have been reported in the context of maternal and newborn health elsewhere (O'Rourke et al. 1998; Manandhar et al. 2004; More et al. 2008; Nahar et al. 2012; Colbourn et al. 2013). However, although both participatory action cycles and QI using PDSA cycles engage users in monitoring and evaluation, PDSA cycles centre around the testing of change ideas, which are trialled on a small scale, outcomes are assessed for improvement, and only then are change ideas scaled up. Like some participatory action cycles, QI is an iterative process. In the learning sessions that occur before each action period, a new topic is introduced, and volunteers will develop change ideas around these. However, the interventions from past change ideas are still implemented. Therefore, the overall impact of QI comes from the cumulative impact of each change idea introduced throughout the course of the intervention. Of the three examples of community-level QI mentioned in the introduction, only the intervention in Ethiopia reported engaging community members to improve care-seeking using methods similar to the PDSA cycles within EQUIP. In the Ethiopia intervention, health-seeking behaviours related to antenatal care, health facility delivery, and post-natal care increased (Sibley et al. 2014). Our results indicate that the use of PDSA cycles by village volunteers enabled responsiveness to context-specific maternal and newborn health problems. Real-time data collected by volunteers to monitor change ideas suggested that, here too, health-seeking behaviours around maternal and newborn health were improving. Qualitative data highlighted the perceptions of mothers, fathers, village leaders and health facility staff, which also suggested that facility births and birth preparedness in particular were increasing. A planned impact evaluation will assess whether these perceived increases are measurable, of public health relevance, district-wide, and attributable to community-level QI.

A necessary consideration within participatory research interventions like EQUIP is the unique ethical concerns that may arise, particularly when trying to respect the autonomy of community members in decision-making (Buchanan et al. 2007; 
Flicker et al. 2007). For example, outsiders may perceive some of the change ideas indicated in Table 3 as being harsh, or even unethical; in particular, the use of fines against women who deliver at home in Tanzania. There is the temptation to appeal to western-held standards of conduct, which may not be conducive to participatory methods. However, with these points of potential ethical contention in mind, it would be valuable for future research to fully explore who participates in community-based interventions and why. Depending on who community representatives are and how they are selected, community participation may serve as a platform for already dominant groups or individuals to act out their authority (Morgan 2001; Braunack-Mayer and Louise 2008).

With over 300 village volunteers in Tanzania and almost 1000 in Uganda, supporting them to apply QI methods required extensive mentoring and coaching by EQUIP staff and QI mentors, with considerable human resource and financial implications. A detailed costing analysis will follow. Working within existing structures that recognize the contribution of volunteers may present part of the solution. Additionally, mentorship in both countries was provided by pre-existing government employees, suggesting some future potential for their routine work to be adapted to encompass QI.

\section{Limitations}

In Tanzania, data were collected from only four villages, although strong consistency of responses from volunteers throughout additional villages in Tandahimba during focus group discussions and confirmation of findings with EQUIP staff and QI mentors suggest that these results are likely transferrable throughout the intervention district. The Ugandan study focused on the feasibility of the EQUIP intervention and as such, was less comprehensive than that of Tanzania.

As implementation of the EQUIP intervention continued beyond the data collection periods of the studies here (November 2012 in Tanzania and May 2013 in Uganda), later insights gained may move beyond those expressed in this article. Furthermore, despite efforts to verify volunteer data wherever possible, with such a large number of volunteers between both countries, it is likely that not all data was checked as thoroughly as it should have been. Therefore, there may not have been accurate representation of local data in all run charts, and it is probable that not all run charts were plotted correctly. To overcome this limitation, ongoing validation of data collected by volunteers and plotted by volunteers was essential.

\section{Conclusion}

Community members can be engaged to use PDSA cycles as part of the QI participatory research approach. This approach has enabled them to address their health problems, to stimulate engagement with health facility staff and to contribute positively to changing social norms. However, the amount of mentoring and coaching needed could be challenging in some settings. Community-level QI has put people at the centre of the health system where community members recognize important benefits to their individual capacity as well as to maternal and newborn health outcomes.

\section{Funding}

The research leading to these results has received funding from the European Union Seventh Framework Programme FP7/ 2007-2013 under grant agreement no. 265827.

\section{The EQUIP Study Team}

U Baker, H Balidawa, R Byaruhanga, J Jaribu, D Kajjo, J Kalungi, A Majura, A Mussa, P Okong, Y Sedekia, and G Tomson

\section{Ethical Approval}

Ethics approval was granted by the ethics review boards of the London School of Hygiene and Tropical Medicine, Ifakara Health Institute (Tanzania), Makerere University (Uganda), the Tanzanian National Institute for Medical Research, the Tanzanian Commission for Science and Technology and the Ugandan National Council for Science and Technology.

Conflict of interest statement. None declared.

\section{References}

Adam T, Lim SS, Mehta S et al. 2005. Cost effectiveness analysis of strategies for maternal and neonatal health in developing countries. British Medical Journal 331: 1107.

Bhutta Z, Lassi Z, Pariyo G, Huicho L. 2011. Global Experience of Community Health Workers for Delivery of Health-Related Millennium Development Goals: A Systematic Review, Counry Case Studies, and Recommendations for Integration into National Health Systems. Geneva: World Health Organization, Global Health Workforce Alliance.

Bhutta ZA, Chopra M, Axelson H et al. 2010. Countdown to 2015 decade report (2000-10): taking stock of maternal, newborn, and child survival. Lancet 375: 2032-44.

Bhutta ZA, Darmstadt GL, Hasan BS, Haws RA. 2005. Community-based interventions for improving perinatal and neonatal health outcomes in developing countries: a review of the evidence. Pediatrics 115: 519-617.

Bloor G. 1999. Organisational culture, organisational learning and total quality management: a literature review and synthesis. Australian Health Review 22: 162-79.

Braunack-Mayer A, Louise J. 2008. The ethics of community empowerment: tensions in health promotion theory and practice. Promotion e Education 15: 5-8.

Buchanan DR, Miller FG, Wallerstein N. 2007. Ethical issues in community-based participatory research: balancing rigorous research with community participation in community intervention studies. Progress in Community Health Partnerships 1: 153-60.

Colbourn T, Nambiar B, Bondo A et al. 2013. Effects of quality improvement in health facilities and community mobilization through women's groups on maternal, neonatal and perinatal mortality in three districts of Malawi: MaiKhanda, a cluster randomized controlled effectiveness trial. International Health 5: 180-95.

Cornwall A, Jewkes R. 1995. What is participatory research? Social Science Medicine 41: 1667-76.

Doran G. 1981. There's a S.M.A.R.T. way to write management's goals and objectives. Management Review 70: 35-9. 
du Mortier S, Arpagaus M. 2005. Quality improvement programme on the frontline: an International Committee of the Red Cross experience in the Democratic Republic of Congo. International Journal for Quality in Health Care 17: 293-300.

EQUIP. 2011. EQUIP: Expanded Quality Improvement Using Information Power. http://www.equip-project.eu/, accessed 18 February 2012.

Flicker S, Travers R, Guta A, Mcdonald S., Meagher A. 2007. Ethical dilemmas in community-based participatory research: recommendations for institutional review boards. Journal of Urban Health 84: 478-93.

Hanson C. 2013. The Epidemiology of Maternal Mortality in Southern Tanzania. Ph.D. Thesis, London School of Hygiene and Tropical Medicine.

Hanson C, Waiswa P, Marchant $\mathrm{T}$ et al. 2014. Expanded quality management using information power (EQUIP): protocol for a quasi-experimental study to improve maternal and newborn health in Tanzania and Uganda. Implement Sci 9: 41.

Hunt P, Backman G. 2008. Health systems and the right to the highest attainable standard of health. Health and Human Rights 10: 81-92.

Imdad A, Bhutta ZA. 2013. Nutritional management of the low birth weight/preterm infant in community settings: a perspective from the developing world. Journal of Pediatrics 162: S107-14.

Langley G. 2009. The Improvement Guide: A Practical Approach to Enhancing Organizational Performance. San Francisco, CA: Jossey-Bass.

Larsson EC, Thorson AE, Pariyo G et al. 2012. Missed opportunities: barriers to HIV testing during pregnancy from a population based cohort study in rural Uganda. PLoS One 7: e37590.

Manandhar DS, Osrin D, Shrestha BP et al. 2004. Effect of a participatory intervention with women's groups on birth outcomes in Nepal: cluster-randomised controlled trial. Lancet 364: 970-9.

Marston C, Renedo A, Mcgowan CR, Portela A. 2013. Effects of community participation on improving uptake of skilled care for maternal and newborn health: a systematic review. PLoS One 8: e55012.

Mayuge District Government. 2010. Mayuge District Government Five-Year Plan 2010/2011-2014/2015. Kampala. http://npa.ug/wp-content/ themes/npatheme/documents/East/Mayuge DDP.pdf, accessed July 2013.

Mkai C, Mbogoro D. 2004. The Regional and District Census Brief. Dar es Salaam.

More NS, Bapat U, Das S et al. 2008. Cluster-randomised controlled trial of community mobilisation in Mumbai slums to improve care during pregnancy, delivery, postpartum and for the newborn. Trials 9: 7.

Morgan LM. 2001. Community participation in health: perpetual allure, persistent challenge. Health Policy Plan 16: 221-30.

Moyer CA, Dako-Gyeke P, Adanu RM. 2013. Facility-based delivery and maternal and early neonatal mortality in sub-Saharan Africa: a regional review of the literature. African Journal of Reproductive Health 17: 30-43.

Nahar T, Azad K, Aumon BH et al. 2012. Scaling up community mobilisation through women's groups for maternal and neonatal health: experiences from rural Bangladesh. BMC Pregnancy Childbirth 12: 5.

National Bureau of Statistics. 2013. Population distribution by administrative units: 2012 population and housing census. Dar es Salaam, Tanzania: The United Republic of Tanzania.

National Bureau of Statistics and ICF Macro. 2011. Tanzania Demographic and Health Survey 2010. Dar es Salaam, Tanzania: National Bureau of Statistics and ICF Macro.
O'Rourke K, Howard-Grabman L, Seoane G. 1998. Impact of community organization of women on perinatal outcomes in rural Bolivia. Rev Panam Salud Publica 3: 9-14.

Pope C, Ziebland S, Mays N. 2000. Analysing qualitative data. British Medical Journal 320: 114-16.

Prata N, Sreenivas A, Vahidnia F, Potts M. 2009. Saving maternal lives in resource-poor settings: facing reality. Health Policy 89: 131-48.

Prost A, Colbourn T, Seward N et al. 2013. Women's groups practising participatory learning and action to improve maternal and newborn health in low-resource settings: a systematic review and meta-analysis. Lancet 381: 1736-46.

Rutenberg N, Watkins SC. 1997. The buzz outside the clinics: conversations and contraception in Nyanza Province, Kenya. Studies in Family Planning 28: 290-307.

Schiffman J, Darmstadt GL, Agarwal S, Baqui AH. 2010. Communitybased intervention packages for improving perinatal health in developing countries: a review of the evidence. Seminars in Perinatology 34: 462-76.

Shah IH, Say L. 2007. Maternal mortality and maternity care from 1990 to 2005: uneven but important gains. Reproductive Health Matters 15: $17-27$.

Shaikh BT, Hatcher J. 2005. Health seeking behaviour and health service utilization in Pakistan: challenging the policy makers. Journal of Public Health 27: 49-54.

Sibley LM, Tesfaye S, Fekadu Desta B et al. 2014. Improving maternal and newborn health care delivery in rural amhara and oromiya regions of ethiopia through the maternal and newborn health in ethiopia partnership. Journal of Midwifery Womens Health 59(Suppl. 1):S6-S20.

The Planning Commission United Republic of Tanzania. 1997. Mtwara Region Socioeconomic Profile. Dar es Salaam: Regional Commissioner's Office, Mtwara.

Uganda Bureau of Statistics. 2009. 2009 Statistical Abstract. Kampala, Uganda: Uganda Bureau of Statistics.

Uganda Bureau of Statistics \& ICF International. 2012. Uganda Demographic and Health Survey 2011. Kampala, Uganda, Calverton, Maryland: Uganda Bureau of Statistics and ICF International.

Umar N, Litaker D, Terris DD. 2009. Toward more sustainable health care quality improvement in developing countries: the "little steps" approach. Quality Management in Health Care 18: 295-304.

United Nation's Children's Fund (UNICEF), World Health Organization (WHO), United Nation's Department of Economic and Social Affairs (UNDESA) and The World Bank. 2012. Mortality Rate, Neonatal (Per 1,000 Live Births). Washington, DC: The World Bank.

United Nations. 2013. The Millennium Development Goals Report 2013. New York: United Nations.

United Nations Department of Economic and Social Affairs. 2011. The Millennium Development Goals Report. New York: United Nations; Department of Economic and Social Affairs.

Wallin L, Malqvist M, Nga NT et al. 2011. Implementing knowledge into practice for improved neonatal survival; a cluster-randomised, community-based trial in Quang Ninh province, Vietnam. BMC Health Services Research 11: 239.

WHO, UNICEF, UNFPA and THE World Bank. 2012. Trends in Maternal Mortality: 1990 to 2010. Geneva: The World Bank.

World Health Organization. 2007. Everybody's Business: Strengthening Health Systems to Improve Health Outcomes-WHO's Famework for Action. Geneva, Switzerland: World Health Organization.

World Health Organization. 2010. Working with Individuals, Families, and Communities to Improve Maternal and Newborn Health. Geneva, Switzerland: World Health Organization. 